${ }^{5}$ Gordon-Smith EC. Bone-marrow failure: diagnosis and treatment. $\mathrm{Br} \mathcal{F}$ Haematol 1969;16,suppl: 167-75.

${ }^{6}$ Najean Y, Pecking A, Broquet $M$. Anémies réfractaires avec myéloblastose partielle. Analyse d'un protocole, groupant 79 cas. I-Caractères cliniques et évolution sous androgénothérapie. Nouv Rev Fr Hematol Blood Cells 1976;16:68-80.

${ }^{7}$ Ricci P, Baccarani M, Zaccaria A, Santucci MA, Tura S. Clinical contribution to the knowledge of hemopoietic dysplasias: long term follow-up of 13 patients with refractory anemia. Acta Haematol (Basel) 1978;60: 10-20.

${ }^{8}$ Milner GR, Testa NG, Geary CG, et al. Bone marrow culture studies in refractory cytopenia and 'smouldering leukaemia.' Br $\mathcal{F}$ Haematol 1977; $35: 251-61$.

9 Faille A, Dresch C, Poirier O, Balitrand N, Najean Y. Prognostic value of in vitro bone marrow culture in refractory anaemia with excess of myeloblasts. Scand f Haematol $1978 ; 20: 280-6$.

10 Valera E, Good RA. Studies on the pathogenesis of refractory anaemia. Am F Med 1980;68:381-5.

${ }^{11}$ Kagan WA, Ascensao JL, Fialk MA, Coleman M, Valera EB, Good RA. Studies on the pathogenesis of aplastic anemia. Am f Med 1979;66: 444-9.

\section{Function of the transplanted heart}

How well does the transplanted (and therefore denervated) heart perform? The immediate and practical answer is, well enough, as the activities of patients such as $\mathrm{Mr}$ Keith Castle have shown. But the physiological aspects have been studied in more detail by Schroeder and his colleagues in Stanford, California. ${ }^{1}$

In the surgical technique of orthotopic cardiac transplantation the patient retains the posterior walls of his own atria. The donor heart is sutured to the atria and great vessels and the surgeon does nothing to the valves, ventricles, arterial supply, and much of the atrial muscle, including in most instances the sinoatrial node. An improvement in cardiac output is usual immediately after the operation, though measurements have shown that the stroke volume and cardiac output remain below normal for the first few days. ${ }^{2}$

In the longer term transplanted hearts do not become innervated again. ${ }^{3}$ The lack of yagal tone is shown by the high resting heart rate, usually $90-100 / \mathrm{min}$, with no sinus arrhythmia. Electrocardiographic monitoring confirms that the heart rate is more or less constant. The pulse rate increases slowly, however, with exercise: peak rates, which are about $150 / \mathrm{min}$, do not occur until after five minutes. Slowing of the heart rate is also delayed as compared with normal. These changes parallel and are probably caused by changes in circulating catecholamine concentrations.

Cardiac catheterisation in healthy recipients has shown normal resting pressures in the transplanted hearts, with outputs in the low normal range. ${ }^{3}$ On exercise the left ventricular filling pressure rises, in contrast to normal subjects, whose filling pressures remain low. As the exercise continues and the heart accelerates so the filling pressure falls towards normal again, while the cardiac output progressively rises. Both at rest and on exercise the arteriovenous oxygen difference is wider than normal for a given oxygen uptake. Moreover, during exercise arterial lactate concentrations rise unduly. These differences suggest that the transplanted heart, though capable of increasing its output, does not quite meet the needs of the body, probably because of the limitation of stroke volume.

Left ventricular volumes have been calculated in a few recipients who have had tantalum markers attached to the donor left ventricular muscle at the time of operation and who have been examined later by fluoroscopy. ${ }^{4}$ In these circumstances atrial pacing causes a reduction in ventricular volumes and no change in cardiac output. Increasing the venous return by raising the legs augments left ventricular end-diastolic and stroke volumes and increases the cardiac output without changing the heart rate. These results confirm the transplanted heart's dependence on the Frank-Starling mechanism (which relates the force of contraction to the stretching of the heart muscle), as suggested by the changes in filling pressure on exertion.

The healthy transplanted heart is, therefore, slightly embarrassed by its lack of innervation. The lack of vagal tone is apparent as a resting tachycardia, and the lack of sympathetic drive limits the increase in stroke volume on exertion. Nevertheless, the denervated heart manages to perform adequately for most levels of activity, adjusting its stroke volume by the Frank-Starling mechanism and its rate in response to circulating catecholamines.

${ }^{1}$ Schroeder JS. Hemodynamic performance of the human transplanted heart. Transplant Proc 1979;11:304-8.

2 Stinson EB, Caves PK, Griepp RB, Oyer PE, Rider AK, Shumway NE. Hemodynamic observations in the early period after human heart transplantation. $\mathcal{F}$ Thorac Cardiovasc Surg 1975;69:264-70.

${ }^{3}$ Clark DA, Schroeder JS, Griepp RB, et al. Cardiac transplantation in man. Review of first three years' experience. Am f Med 1973;54:563-76.

${ }^{4}$ Ingels NB, Ricci DR, Daughters GT, Alderman EL, Stinson EB. Effects of heart rate augmentation on left ventricular volumes and cardiac output of the transplanted human heart. Circulation 1977;56,suppl 2: 32-7.

5 Pope SE, Ingels NB, Daughters GT, Schroeder JS. In vivo demonstration of the Frank-Starling mechanism in the human denervated heart. $A m \mathcal{F}$ Cardiol $1978 ; 41: 432$.

\section{Mechanisms of chemical carcinogenesis}

Research workers in carcinogenesis are fired by two considerations. Firstly, they hope that better understanding of its mechanisms will lead to the possibility of preventing human cancer. Secondly, their study of the life processes that may be relevant to carcinogenesis by using the latest molecular biological techniques adds to the store of human knowledge and is intellectually satisfying. Unfortunately, those who know most about human cancer and those best able to use new molecular biological techniques constitute different populations with only limited overlap. One consequence of this divide has been the recent fashion for the results of a laboratory experiment, completed in only a few hours, and in the absence of evidence of other kinds, to be interpreted as indicating that man should change his life style in some vital way. How we can best and most quickly check whether man will really benefit from such proposed changes is thus one of the most important questions to be answered.

In his introduction to the British Medical Bulletin's recent review of chemical carcinogenesis, ${ }^{1}$ Peter Brookes indicates that during the past 15 years most progress has been made in our understanding of the tumour-initiating stage of carcinogenesis. What we need to do now, he suggests, is to try to elucidate the nature of tumour promotion in terms of molecular mechanisms. The past 15 years has indeed seen rapid advances in knowledge of how chemically unreactive substances may be converted in vivo to electrophilic metabolites capable of binding to DNA, of the nature of damage to DNA, and of the ways in which such damage may be correctly or incorrectly 